\title{
Working Conditions and Performance of Tertiary Teachers at UM Panabo College
}

\author{
Leavic G. Maghanoy \\ Master in Management, Business Professor, The University of Mindanao \\ DOI: https://dx.doi.org/10.47772/IJRISS.2021.5501
}

\begin{abstract}
The main objective of the study is to determine which domain of working conditions best influences the performance of tertiary teachers. The quantitative non-experimental design utilizing correlation technique was used in the study. The respondents of the study were the 45 tertiary teachers of UM Panabo College. Mean, Pearson-r and Regression Analysis were the statistical tools employed to interpret the data gathered. The findings of the study revealed a high level of working conditions of tertiary teachers at UM Panabo College. It was also revealed that the level of performance at UM Panabo College was very high. The test of relationship between variables confirmed significant relationship between working conditions and performance of tertiary teachers at UM Panabo College. Based on the results, there was no specific domain on working conditions that best influences the performance of tertiary teachers of UM Panabo College in its singular capacity. However, all indicators are needed in combination to significantly influence the performance of tertiary teachers at UM Panabo College.
\end{abstract}

Keywords: Working conditions, Performance

\section{BACKGROUND OF THE STUDY}

$\mathrm{M}$ embers of the Higher Education Institution (HEI) like colleges and universities cannot accomplish their missions completely without dedicated and vital faculty members. Nowadays educators are below stress to dramatically improve student learning. Practical studies show that in achieving this goal, highly performing instructors are the maximum critical elements to be considered. This way has something to do with giving quality guidance to students by enhancing one's execution since the educator's work performance is one of the components on acknowledging such an objective. Accordingly, it is evident that businesses are specific in employee's performance since it influences the profitability of their organization. Therefore, it is evident that employers are particular in employee's performance since it affects the productivity of their company (Narciso, 2017).

On the other side, working conditions are also necessary, regardless of the proposal for reforms; in the end, the effectiveness will somehow depend on the way the management strengthens it. The things that educators do is intricately connected with their thoughts and emotions; their inner states. Educators' thoughts and emotions are intricately attached to the environment under which they work. Working conditions incorporates few components, which contributes either positively or adversely to accomplishing most extreme employees' performance. The idea of the physical condition under which employees work is imperative to yield, workplaces that are excessively hot and poorly ventilated can influence their performance (Leithwood, 2006; Ali, Ali, Adan, 2013).

In UM Panabo College, some of its employees are expressing their sentiments that the school where they are employed does not have enough updated technology and encounter problems on working conditions mainly learning resources. This situation affects the performance of these workers as affirmed through an interview conducted by the researcher in the person of A.P. Lasher.

Given these circumstances, the researcher perceives the need and drive of undertaking the study since there has not been a clear study that comes across with the specific domains on working conditions that affect performance in the field of academe. There are existing studies on the two variables as mentioned above; however, those studies dealt only on identifying factors in a foreign context and on the main variables whereas in this study, the researcher covers the specific domain of each variable, and the concentration is in the local set up thus making the study unique from others. Also, this will contribute to the existing gap in the literature and will give a specific contribution to the workplace and generates new knowledge of working conditions. This research will, therefore, seek to find a significance of the relationship and which domain in working conditions significantly influences the performance of tertiary teachers at UM Panabo College.

\section{THEORETICAL FRAMEWORK}

This study is anchored on the proposition of Oswald (2012) who stated that working conditions affect the performance level of employees. If working conditions are not existent, then the performance of employees will be affected. The absence of office building and equipment are some of the examples of this effect.

The study was supported by Herzberg's Two-factor theory as mentioned by Okolo (1993). Frederick Herzberg labeled these factors as motivators (because each was associated with intense effort and good performance) such as working condition and job security; and hygiene factors, such as recognition and advancement. This hygiene factor is the dissatisfier, while motivators are the satisfier of employees. Herzberg found job dissatisfaction to be associated primarily with elements in the working conditions. So working 
conditions and performance is related to this theory because according to Herzberg's interpretation, an individual will experience no job dissatisfaction when he or she has no grievances about hygiene factors, therefore if this happens, the employee will be satisfied leading to a boost in his or her performance.

Besides, this study was also supported by Bushiri (2014) who stated that immediate supervisors reinforce employees, they help them in collecting and distributing the resources that are necessary for them to perform their tasks effectively and efficiently, and also they encourage when an employee does exemplary work. Supervisors are included in the working conditions; their role is to positively motivate, inspire and boosts the self-esteem of their subordinates if these things are done favorably employees will have an increase in performance.

Lastly, Eluka and Nwonu (2014) presented the ideas that in an organization, employees are treated as the most significant assets. Organizational resources are used by the talented and work driven employees to create and deliver value. Successful and flexible organization attracts and retains the right talents for the right job. Working conditions are needed so that the employees will satisfy the customers and organization performance in the world of competition. Standard facilities help employees to do their tasks effectively. Employees emphasize working conditions as the most valuable factor to their satisfaction, yet the regular replacement and maintenance of facilities should be not be done to do it but should be regularly maintained so the workforce can have their optimal enjoyment while doing their assigned duty.

\section{CONCEPTUAL FRAMEWORK}

As shown in the figure below, the framework illustrates the relationship between the independent and dependent variable. The independent variable is the Working Conditions with the following indicators: time, empowerment, leadership, professional development, and facilities and resources (Hirsch et al., 2007).

In this study, time pertains to the available period to plan, collaborate and deliver instruction and disregard barriers to make optimal instructional time during the school day. Second, empowerment refers to the heavy workload and noninstructional requirements that are infringed upon the time of teachers to focus on instruction that may affect the quality of education. Third, leadership refers to the involvement of the teacher in decisions that affect classroom and practices in school, the school leadership's ability to create trust and supportive environments that address the concerns of the teachers. Fourth, professional development refers to the availability and quality of learning opportunities for teachers to improve their instruction. Lastly, facilities and resources pertain to the accessibility of instructional materials, technology, office communication, and school resources to instructors.
The dependent variable is the Performance with its indicators namely: professional knowledge, instructional planning, instructional delivery, assessment of and for learning, learning environment, professionalism and student academic progress (Stronge, 2012).

In this study, professional knowledge refers to instructors' exhibit an understanding of the curriculum, subject content and the students' developmental necessities by providing necessary experiences in learning. Second, instructional planning pertains to the plan of the teacher using the school's curriculum, effective strategies, resources and data to meet all of the students' needs. Third, instructional delivery refers to how teachers effectively engage their students in learning with the use of different instructional strategies to achieve individual learning needs. Fourth, assessment of and for learning refers to the way the teachers' analyses, systematically collects, and uses all necessary data to assess student academic progress, delivery methods and guide educational content and provide timely feedback to both parents and students throughout the school year. Fifth, the learning environment pertains to instructors' usage of routines, procedures, and resources to contribute a respectful, safe, favorable, student-centered condition that is conducive to learning. Sixth, professionalism refers to the consistency of the teacher with the commitment to professional ethics, effectively communicates, and takes responsibility and participates in enhancing the student learning through professional growth.

Finally, student academic progress refers to the work of the instructor results in satisfactory, measurable and appropriate student academic development.

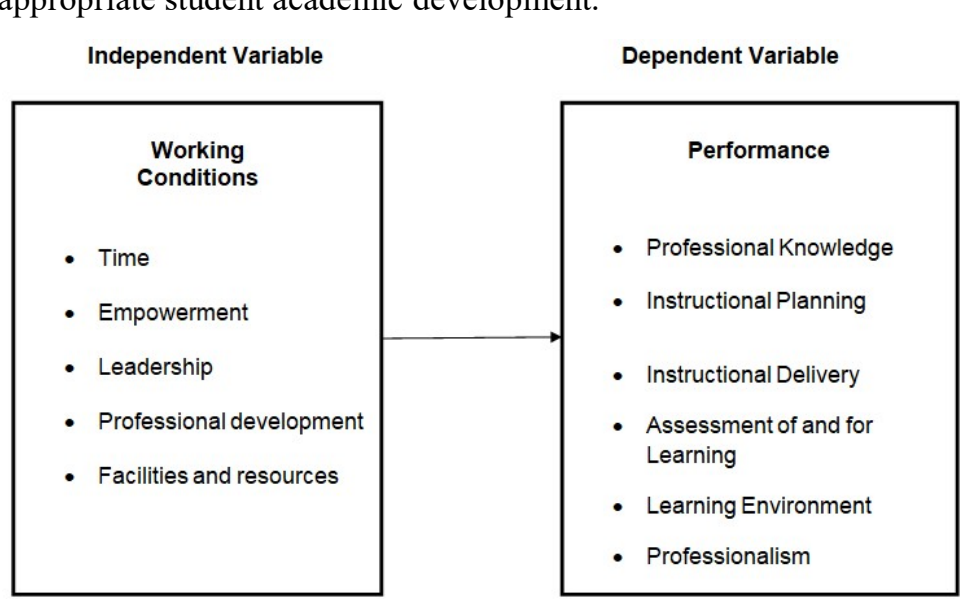

Figure 1. The Conceptual Paradigm Showing the Variables of the Study

\section{Research Objectives}

This study was conducted to determine which domain of working conditions best influences the performance of tertiary teachers at UM Panabo College. Specific objectives are as follows:

1. To assess the level of working conditions of tertiary teachers at UM Panabo College terms of: 
1.1 time;

1.2 empowerment;

1.3 leadership;

1.4 professional development; and

1.5 facilities and resources.

2. To ascertain the level of performance of tertiary teachers at UM Panabo College in terms of:

1.1 professional knowledge;

1.2 instructional planning;

1.3 instructional delivery;

1.4 assessment of and for learning;

1.5 learning environment;

1.6 professionalism; and

1.7 student academic progress.

3. To determine the significance of the relationship between working conditions and performance of tertiary teachers at UM Panabo College.

4. To find out which domain of working conditions best influences performance of tertiary teachers at UM Panabo College.

\section{Hypothesis}

The following null hypotheses were tested at 0.05 level of significance:

1. There is no significant relationship between working conditions and performance of tertiary teachers.

2. There is no domain of working conditions that best influences performance of tertiary teachers.

\section{Research Design}

This study employed the quantitative nonexperimental design utilizing correlation technique because this reveals the significance of the relationship of working conditions and performance. According to Creswell (2014), correlational study shows the relationship between two or more variables, that is, how a variable varies with another. In this case, the idea of Creswell is appropriate in the current study because it revealed the significance of the relationship between working conditions and performance of tertiary teachers.

\section{Research Locale}

The study was conducted in Panabo City, Davao del Norte. The researcher chose Panabo city specifically the UM Panabo College mainly because there is a problem existing in the area. Panabo is a third-class component city in the province of Davao del Norte, the Philippines bordering Davao City to its northeast. The city has an area of 25,123 hectares (62, 080 acres) and is politically subdivided into 40 barangays. According to the 2010 census, it has a population of 174,364 people.

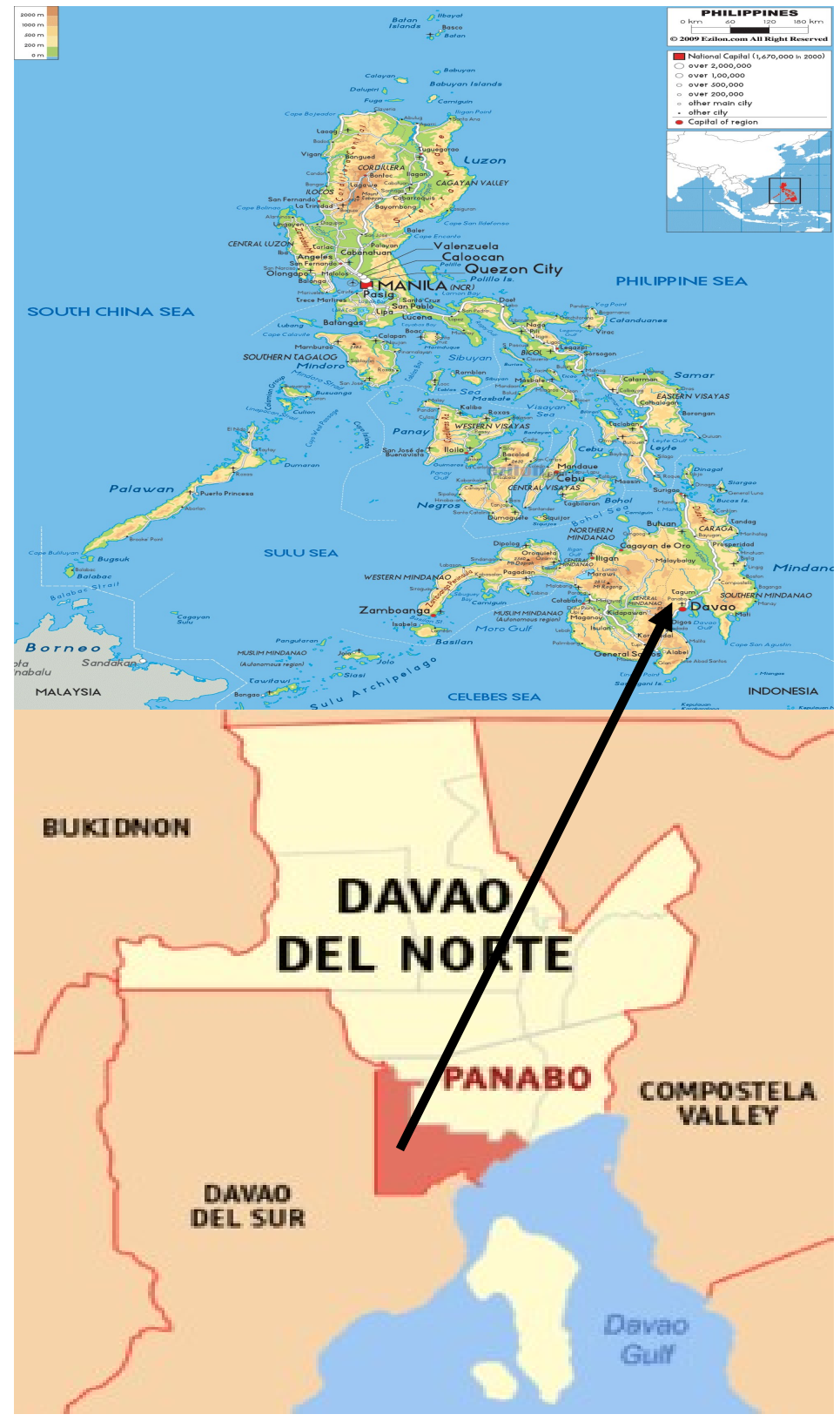

Figure 2. Map of the Philippines Highlighting Panabo City in Davao del Norte

Research Respondents

The respondents were the tertiary teachers at UM Panabo College. The researcher used the complete enumeration or census technique wherein tertiary teachers of UM Panabo College participated in a multi-rater survey. The total number of respondents for this study is 45 . The following were its distribution by departments: Education faculty with six full-time and ten part-time, Business Administration faculty with three full-time and eight parttime, Accounting Technology faculty with one full time and four part-time, and Lastly, Arts and Sciences faculty with five full-time and eight part-time. 
Census (Farooq, 2013) is the complete enumeration of a universe. A universe may be a place, a group of individuals or a particular locality through which we gather the information. Census method is fundamental in some cases like populace enumeration, agriculture census, animal, etc. for gaining vast knowledge. Complete enumeration is used in this investigation because the researcher opted to include all the population in UM Panabo College.

All 45 part-time and full-time tertiary teachers answered and returned the questionnaires. The researcher made clear to the respondents that the participation is voluntary. The study was conducted during the first semester; School Year 2017-2018.

\section{Statistical Treatment}

The response gathered from the questionnaire were tallied and tabulated in a master data sheet. Statistics needed to answer the sub-problems were as follows:

Mean. This was utilized to determine the level of working conditions as well as the performance of the tertiary teachers at UM Panabo College.

Pearson r. This was utilized to determine the significance of the relationship between working conditions and performance of the tertiary teachers at UM Panabo College.

Regression. This was applied to determine which domain in the working conditions best influences performance of tertiary teachers at UM Panabo College.

\section{Research Instrument}

The researcher adapted and modified the survey questionnaire of Applewhite (2009) and Stronge (2012) in this research as a tool in gathering data for working conditions and performance respectively. The said instrument was divided into two parts, the first part deals with the school working conditions with its indicators time, empowerment, leadership, professional development, and facilities and resources and the second part of the instrument deals with performance with its indicators: professional knowledge, instructional planning, instructional delivery, assessment of and for learning, learning environment, professionalism, and student academic progress.

To determine the level of working conditions, the following 5 Point Likert type scale was used:

\begin{tabular}{|c|c|c|}
\hline $\begin{array}{c}\text { Range of } \\
\text { Means }\end{array}$ & $\begin{array}{c}\text { Descriptive } \\
\text { Level }\end{array}$ & Interpretation \\
\hline $4.20-5.00$ & Very High & $\begin{array}{c}\text { This means that the item in working } \\
\text { conditions is always manifested. }\end{array}$ \\
\hline $3.40-4.19$ & High & $\begin{array}{c}\text { This means that the item in working } \\
\text { conditions is oftentimes manifested. }\end{array}$ \\
\hline $2.60-3.39$ & Moderate & $\begin{array}{c}\text { This means that the item in working } \\
\text { conditions is sometimes manifested. }\end{array}$ \\
\hline $1.80-2.59$ & Low & $\begin{array}{c}\text { This means that the item in working } \\
\text { conditions is seldom manifested. }\end{array}$ \\
\hline $1.00-1.79$ & Very Low & $\begin{array}{c}\text { This means that the item in working } \\
\text { conditions is never manifested. }\end{array}$ \\
\hline
\end{tabular}

To determine the level of performance, the following 5 Point Likert type scale was used:

\begin{tabular}{|c|c|c|}
\hline $\begin{array}{c}\text { Range of } \\
\text { Means }\end{array}$ & $\begin{array}{c}\text { Descriptive } \\
\text { Level }\end{array}$ & Interpretation \\
\hline $4.20-5.00$ & Very High & $\begin{array}{c}\text { This means that the item in } \\
\text { performance is always } \\
\text { satisfactory. }\end{array}$ \\
\hline $3.40-4.19$ & High & $\begin{array}{c}\text { This means that the item in } \\
\text { performance is oftentimes } \\
\text { satisfactory. }\end{array}$ \\
\hline $2.60-3.39$ & Moderate & $\begin{array}{c}\text { This means that the item in } \\
\text { performance is sometimes } \\
\text { satisfactory. }\end{array}$ \\
\hline $1.80-2.59$ & Low & $\begin{array}{c}\text { This means that the item in } \\
\text { performance is seldom } \\
\text { satisfactory. }\end{array}$ \\
\hline $1.00-1.79$ & Very Low & $\begin{array}{c}\text { This means that the item in } \\
\text { performance is never satisfactory. }\end{array}$ \\
\hline
\end{tabular}

Remarkably, to test the validity and reliability of the adapted questionnaire, the contents were validated by the internal and external validators. Also, upon the actual conduct of the study, the questionnaire underwent through a pilot test. The comments and suggestions were incorporated into the revision of the questionnaire. The consolidated results were incorporated in the revision of the questionnaires.

\section{RESULTS}

\section{Working Conditions of Tertiary Teachers}

Presented in Table 1 are the responses of the respondents on their level of working conditions which registered an overall mean score is 4.17 or high level indicating that majority of the items regarding working conditions is oftentimes manifested. The generated overall mean score was the result obtained from the mean score of 4.37 or very high working conditions in leadership, 4.28 or very high for working conditions in professional development, 4.27 or very high for working conditions in empowerment, 4.08 or high for working conditions in time, and 3.87 or high for working conditions in facilities and resources.

From the findings, leadership obtained the highest mean score of 4.37 or very high. This is followed by professional development and empowerment with 4.28 and 4.27 mean ratings, respectively. The rest of the indicators obtained mean ratings ranging from 4.08 to 3.87 .

Table 1. Level of Working Conditions of Tertiary Teachers

\begin{tabular}{|c|c|c|c|}
\hline Indicator & SD & Mean & $\begin{array}{c}\text { Descriptive } \\
\text { Level }\end{array}$ \\
\hline Leadership & 0.53 & 4.37 & Very High \\
\hline $\begin{array}{c}\text { Professional } \\
\text { Development }\end{array}$ & 0.55 & 4.28 & Very High \\
\hline Empowerment & 0.65 & 4.27 & Very High \\
\hline Time & 0.72 & 4.08 & High \\
\hline $\begin{array}{c}\text { Facilities and } \\
\text { Resources }\end{array}$ & 0.73 & 3.87 & High \\
\hline Overall & $\mathbf{0 . 5 3}$ & $\mathbf{4 . 1 7}$ & High \\
\hline
\end{tabular}




\section{Performance of Tertiary Teachers}

Depicted in Table 2 are the responses of the respondents on their level of performance that registered an overall mean is 4.35 or very high. This means the performance of the tertiary teachers is always satisfactory. The generated overall mean score was the result obtained from the mean score of 4.42 or very high for learning environment, 4.38 or very high for instructional delivery, professionalism, and professional knowledge, 4.33 or very high for student academic progress, 4.28 or very high for instructional planning, and 4.26or very high for assessment of and for learning.

Based on the result, learning environment obtained the highest mean score of 4.42 or very high. This is followed by instructional delivery, professionalism and professional knowledge with 4.38 mean ratings. The rest of the indicators obtained mean ratings ranging from 4.33 to 4.26 .

Table 2. Level of Performance of Tertiary Teachers

\begin{tabular}{|c|c|c|c|}
\hline Indicator & SD & Mean & $\begin{array}{c}\text { Descriptive } \\
\text { Level }\end{array}$ \\
\hline Learning Environment & 0.33 & 4.42 & Very High \\
\hline Instructional Delivery & 0.27 & 4.38 & Very High \\
\hline Professionalism & 0.34 & 4.38 & Very High \\
\hline Professional Knowledge & 0.29 & 4.38 & Very High \\
\hline $\begin{array}{c}\text { Student Academic } \\
\text { Progress }\end{array}$ & 0.25 & 4.33 & Very High \\
\hline Instructional Planning & 0.32 & 4.28 & Very High \\
\hline $\begin{array}{c}\text { Assessment of and for } \\
\text { learning }\end{array}$ & 0.32 & 4.26 & Very High \\
\hline Overall & $\mathbf{0 . 2 6}$ & $\mathbf{4 . 3 5}$ & Very High \\
\hline
\end{tabular}

Significance on the Relationship between Working Conditions and Performance of Tertiary Teachers at UM Panabo College

Shown in Table 3 are the correlation between working conditions and performance of tertiary teachers. As described in the table, it presented an over-all r-value of .538 with a probability value of $<.05$. This implies that the higher is the UM Panabo College's practice of working conditions, the higher would be the performance of their tertiary teachers. . Therefore, the null hypothesis of no significant relationship between working conditions and performance was rejected.

However, an in-depth analysis of the matrix of correlation showed that time and empowerment showed no significant relationship with professional knowledge, an indicator of performance. Also, time had no significant relationship with instructional planning, another indicator of performance. Next, time showed no significant relationship with instructional delivery, an indicator of performance. Time also showed no significant relationship with learning environment, an indicator of performance. Then, time, leadership, professional development, and facilities and resources showed no significant relationship with student academic progress, another indicator of performance. Their probability value ranged from .054 to .149 which is greater than 0.05 significance level set in this study, hence no significant relationship of these items were recorded.

However, as reflected in the table, the over-all rvalue and the $p$-values for the correlation between indicators of working conditions towards performance are as follows: for professional knowledge and working conditions with a registered r-value of.447 and p-value of $<.05$; for instructional planning and working conditions with obtained $r$ value of .451 and $\mathrm{p}$-value of $<.05$; for instructional delivery and working conditions with marked r-value of .444 and pvalue of $<.05$, for assessment of and for learning and working conditions with recorded r-value of .555 and $p$-value of $<.05$, for learning environment and working conditions with $r$-value of .493 with $\mathrm{p}$-value $<.05$, for professionalism and working conditions with $\mathrm{r}$-value of .490 and $\mathrm{p}$-value of $<.05$ as well; for student academic progress and working conditions with $\mathrm{r}$ value of .336 with $p$-value of $<.05$. These relationships signaled the researcher to further test the influence of the above-mentioned performance domain on working conditions. Regression analysis was employed for the test.

Table 3. Significance of the Relationship between Working Conditions and Performance of Tertiary Teachers at UM Panabo College

\begin{tabular}{|c|c|c|c|c|c|c|}
\hline \multirow[b]{2}{*}{ Performance } & \multicolumn{6}{|c|}{ Working Conditions } \\
\hline & Time & $\begin{array}{l}\text { Empo } \\
\text { werme } \\
\text { nt }\end{array}$ & $\begin{array}{l}\text { Leader } \\
\text { ship }\end{array}$ & $\begin{array}{l}\text { Profess } \\
\text { ional } \\
\text { Develo } \\
\text { pment }\end{array}$ & $\begin{array}{l}\text { Facilit } \\
\text { ies } \\
\text { and } \\
\text { Resou } \\
\text { rces }\end{array}$ & Overall \\
\hline \multirow{2}{*}{$\begin{array}{l}\text { Professional } \\
\text { Knowledge }\end{array}$} & .273 & .287 & $.389^{*}$ & $.465^{*}$ & $.473^{*}$ & $.447^{*}$ \\
\hline & .069 & .056 & .008 & .001 & .001 & .002 \\
\hline \multirow{2}{*}{$\begin{array}{l}\text { Instructional } \\
\text { Planning }\end{array}$} & 277 & $.417^{*}$ & $.330^{*}$ & $.345^{*}$ & $.501^{*}$ & $.451^{*}$ \\
\hline & .066 & .004 & .027 & .020 & .000 & .002 \\
\hline \multirow{2}{*}{$\begin{array}{l}\text { Instructional } \\
\text { Delivery }\end{array}$} & .267 & $.391^{*}$ & $.380^{*}$ & $.435^{*}$ & $.405^{*}$ & $.444^{*}$ \\
\hline & .077 & .008 & .010 & .003 & .006 & .002 \\
\hline \multirow{2}{*}{$\begin{array}{l}\text { Assessment } \\
\text { of and for } \\
\text { Learning }\end{array}$} & $.315^{*}$ & $.489^{*}$ & $.534^{*}$ & $.446^{*}$ & $.554^{*}$ & $.555^{*}$ \\
\hline & .035 & .001 & .000 & .002 & .000 & .000 \\
\hline \multirow{2}{*}{$\begin{array}{l}\text { Learning } \\
\text { Environment }\end{array}$} & .227 & $.387^{*}$ & $.502^{*}$ & $.487^{*}$ & $.499^{*}$ & $.493^{*}$ \\
\hline & .133 & .009 & .000 & .001 & .000 & .001 \\
\hline \multirow{2}{*}{$\begin{array}{l}\text { Professionali } \\
\text { sm }\end{array}$} & $.341^{*}$ & $.437^{*}$ & $.418^{*}$ & $.416^{*}$ & $.443^{*}$ & $.490^{*}$ \\
\hline & .022 & .003 & .004 & .005 & .002 & .001 \\
\hline \multirow{2}{*}{$\begin{array}{l}\text { Student } \\
\text { Academic } \\
\text { Progress }\end{array}$} & .290 & $.322^{*}$ & .218 & .279 & .283 & $.336^{*}$ \\
\hline & .054 & .031 & .149 & .064 & .059 & .024 \\
\hline \multirow{2}{*}{ Overall } & $.330^{*}$ & $.457^{*}$ & $.467^{*}$ & $.480^{*}$ & $.531^{*}$ & $.538^{*}$ \\
\hline & .027 & .002 & .001 & .001 & .000 & .000 \\
\hline
\end{tabular}

${ }^{*} p<.05$ 
Significance on the Influence of Working Conditions on Performance of Tertiary Teachers at UM Panabo College

Exhibited in Table 4 is the regression analysis to test the significant influence of working conditions on performance of tertiary teachers of UM Panabo College. The result showed that the $\mathrm{r}^{2}$ or coefficient of determination value registered at 0.311 which implies that the variance of working conditions explains 31.1 percent of the total variability of performance. The remaining 68.9 percent of the variation in performance is attributed to other variables not covered in this study. The obtained $\mathrm{r}$-value of 0.558 indicates a strong positive relationship between the working conditions and performance of tertiary teachers.

Based on the results, there is no specific domain on working conditions that best influences the performance of tertiary teachers of UM Panabo College in its singular capacity since all probability values are more than .05 ranging from .185 to .999 . However, all indicators are needed in combination to significantly influence the performance of tertiary teachers at UM Panabo College. The F - value of 3.526 with $p<0.05$ is the evidence of the significant influence of working conditions as a whole on the performance of tertiary teachers.

Table 4. Significance on the Influence of Working Conditions on Performance of Tertiary Teachers of UM Panabo College

\begin{tabular}{|l|l|l|l|l|}
\hline & \multicolumn{5}{|c|}{ Performance } \\
\hline Working Conditions & $\boldsymbol{B}$ & $\boldsymbol{B}$ & $\mathbf{T}$ & Sig. \\
\hline Time & -.008 & -.023 & -.124 & .902 \\
\hline Empowerment & .066 & .165 & .737 & .466 \\
\hline Leadership & .000 & .000 & -.001 & .999 \\
\hline $\begin{array}{l}\text { Professional } \\
\text { Development }\end{array}$ & .070 & .148 & .641 & .525 \\
\hline $\begin{array}{l}\text { Facilities and } \\
\text { Resources }\end{array}$ & .116 & .324 & 1.351 & .185 \\
\hline \multicolumn{4}{|c|}{.558} \\
\hline \multicolumn{3}{|c|}{$R^{2}$} & .311 \\
\hline \multicolumn{2}{|c|}{} & & 3.526 \\
\hline
\end{tabular}

$* p<.05$

\section{CONCLUSION}

Based on the findings, the following conclusions are drawn: the level of working conditions is high. On the other hand, the level of performance is very high. Furthermore, the results find out that there is a significance of the relationship between working conditions and performance of tertiary teachers at UM Panabo College. Lastly, based on the results, there is no domain on working conditions that best influences the performance of tertiary teachers of UM Panabo College. However, all indicators are needed in combination to significantly influence the performance of tertiary teachers at UM Panabo College. The results of the study conform to the anchored proposition of Oswald (2012) working conditions affect performance level of employees. If working conditions is non-existent then the performance of employees will be affected.

\section{RECOMMENDATIONS}

In light of the preceding findings and conclusions, the following recommendations are offered. The researcher recommends that since the level of working conditions is high it can be elevated to very high by first, providing teachers with adequate non-instructional time such as enough periods to take lunch, also, teachers are given time gap to rest before the next class schedule as stated in the comment section in one of the working conditions (self-evaluation) survey questionnaires, teachers need not be given multitask during their vacant time (no class schedule time). Second, faculty members can have a sound way of crafting decision makings and in solving problems thus, they should be given a deep understanding of the things going around the institution particularly the strategic plan through meetings. Third, teachers may possibly have a shared vision with staff; hence, both must have the same strategic direction explained and oriented by the management. Fourth, teachers are advised to purchase more instructional technology like computers, LCD projectors, printers, software and also office supplies so that work will be efficient, faster and simultaneous. Lastly, it is recommended for the administration to consult the internet provider to increase the speed connections sufficient to support instructional practices.

Moreover, since the level of performance is very high it can be maintained in that level by, conducting regular retooling seminar that will particularly tackle a variety of effective instructional and assessment strategies (before, during and after) for students.

Furthermore, the significance of the relationship revealed between variables in the study suggests a need for UM Panabo College to improve and sustain their level of working conditions to performance. Thus, the researcher suggests to the administration to consider work-life balance program that can help empower the tertiary teachers personally and professionally.

Finally, the result that there is no domain on working conditions that best influences the performance of tertiary teachers and all indicators are needed in combination to significantly influence the performance of tertiary teachers is suggestive that it is the right time for the institution especially the UM Panabo College to provide strong emphasis on the employees' time, empowerment, leadership, professional development and facilities and resources which are the domains of working conditions that influence the performance of tertiary teachers as a whole. These can be done by giving the teachers time available to collaborate with their colleagues, having an effective process for making group decisions and solving problems in the faculty, having a shared vision, having sufficient resources available for professional development in the school, and having sufficient access to appropriate instructional materials and resources. Further 
researches regarding the domain of working conditions that would greatly affect the performance may also be conducted to support the hypothesis proposed in this study.

\section{REFERENCES}

[1] Ali, A., Ali, A., \& Adan, A. (2013). Working conditions and employees' productivity in manufacturing companies in SubSaharan African context: Case of Somalia. Educational Research International, 2(2), 68-70. Retrieved from http://www.erint.savap.org.pk/PDF/Vol.2(2)/ERInt.2013(2.209).pdf

[2] Aliakbari, M., \& Amoli, F. (2016). The effects of teacher empowerment on teacher commitment and student achievement. Mediterranean Journal of Social Sciences, 7(4), 649. doi:10.5901/mjss.2016.v7n4p649

[3] Allen, A. (2014). Teachers' perceptions of working conditions: The difference between static and improving schools in Kentucky (Doctoral dissertation). Retrieved from https://digitalcommons.wku.edu/cgi/viewcontent.cgi?referer $=\&$ htt psredir $=1 \& \mathrm{cv}=1 \&=\&$ article $=1061 \&$ context $=$ diss

[4] Applewhite, M. A. (2009). An investigation of elementary teachers' and principals' perceptions of teacher working conditions and academic achievement in North Carolina. Retrieved from https://search.proquest.com/docview/288213900?accountid=31259

[5] Badayai, A. (2012). A theoretical framework and analytical discussion on uncongenial physical workplace environment and job performance among workers in industrial sectors. Procedia Social and Behavioral Sciences, 2. doi:10.1016/j.sbspro.2012.04.214

[6] Barge, J. D. (2013). Teacher keys effectiveness system. Retrieved from https://www.nctq.org/dmsView/TKES Handbook FINAL 7-182013

[7] Berry, B. (2010). Teacher effectiveness: The conditions that matter most and a look to the future. Center for Teaching Quality, 7-8. Retrieved from https://files.eric.ed.gov/fulltext/ED509720.pdf

[8] Bhaga, T. (2010). The impact of working conditions on the productivity of nursing staff in the midwife obstetrical unit of Pretoria West hospital. Retrieved from https://repository.up.ac.za/bitstream/handle/2263/27211/dissertatio n.pdf? sequenc $=$

[9] Bogler, R., \& Somech, A. (2004). Influence of teacher empowerment on teachers' organizational commitment, professional commitment and organizational citizenship behavior in school. Teaching and Teacher Education, 278. doi:10.1016/j.tate.2004.02.003

[10] Bushiri, C. (2014). The impact of working environment on employees' performance: the case of institute of finance management in Dar Es Salaam region. Retrieved from http://repository.out.ac.tz/608/mhrm-dissertation.pdf

[11] Campbell-Pritt, C. (2008). A study of grade distributions and withdrawal for selected courses at a community college in Northeast Tennessee. Retrieved from https://search.proquest.com/docview/230670516?accountid=31259

[12] Chandrasekar, K. (2011). Workplace environment and its impact on organisational performance in public sector organisations. International Journal of Enterprise Computing and Business Systems, 1(1), $1 . \quad$ Retrieved from http://www.ijecbs.com/January2011/N4Jan2011.pdf

[13] Choy, S. P. (1996). Teachers' working conditions. Retrieved from https://nces.ed.gov/pubs97/97371.pdf

[14] Creswell, J. W. (2014). Research design qualitative, quantitative, and mixed method approaches (4th ed).Sage Publications, 18. Retrieved from https://www.researchgate.net/file.PostFileLoader.html?id=5901da d84048541d6c2b1fc3\&assetKey=AS\%3A487723636137986\%401 493293784496
[15] DeMonte, J. (2013). High-quality professional development for teachers: supporting teacher training to improve student learning. Retrieved from https://files.eric.ed.gov/fulltext/ED561095.pdf

[16] Desimone, L. M., Porter, A. C., Garet, M. S., Yoon, K., \& Birman, B. F. (2012). Effects of professional development on teachers' instruction: Results from a three-year longitudinal study. Retrieved from http://outlier.uchicago.edu/computerscience/OS4CS/landscapestud $\mathrm{y} /$ resources/Desimone,Porter,\%20Garet,\%20Yoon,\%20and\%20Bir man, $\% 202002 \% 20(1)$.pdf

[17] Eluka, J. \& Nwonu, C. (2014). A critical review on the effect of working conditions on employee performance: Evidence from Nigeria. Retrieved from https://www.researchgate.net/publication/284183810_A_Critical_ Review_of_The_Effect_of_Working_Conditions_On_Employee Performance_Evidence_From_Nigeria

[18] Erwin, H., Fedewa, A., \& Ahn, S. (2017). Student academic performance outcomes of a classroom physical activity intervention: A pilot study. Retrieved from https://www.iejee.com/index.php/IEJEE/article/view/191

[19] Farooq, U. (2013). What is census method of data collection, advantages \& disadvantages. Retrieved from http://www.studylecturenotes.com/social-researchmethodology/what-is-census-method-of-data-collectionadvantages-disadvantages

[20] Francis, T. M. (2017). Teacher Working Conditions: perceptions of novice and experienced $k-12$ virtual school teachers (Doctoral dissertation). Retrieved from https://digitalcommons.liberty.edu/cgi/viewcontent.cgi?article=24 $23 \&$ context $=$ doctoral

[21] Giri, M. (2014). Teachers' engrossment in professional development in Surkhet Valley. Nepal Journals Online. doi.org/10.3126/jns.v4i0.12865

[22] Hallinger, P. (2005). Instructional leadership and the school principal: A passing fancy that refuses to fade away. Taylor \& Francis Group, 221-239. doi.org/10.1080/15700760500244793

[23] Hirsch, E. (2004). Teacher working conditions are student learning conditions: A report to governor Mike Easley on the 2004 North Carolina teachers working conditions survey. Retrieved from https:////nepc.colorado.edu/sites/default/files/EPRU-0504$110-$

[24] Hirsch, E., Emerick, S., Church, K., \& Fuller, E. (2007). Teacher working conditions are student learning conditions. Retrieved from https://files.eric.ed.gov/fulltext/ED498770.pdf

[25] Ingersoll, R. (2002). High turnover plagues schools. Retrieved from

https://repository.upenn.edu/cgi/viewcontent.cgi?referer=https://w ww.google.com $/$ \&httpsredir $=1$ \&article $=1130 \&$ context $=$ gse pubs

[26] Kitsantas, A., \& Baylor, A. (2001). The impact of the instructional planning self-reflective tool on preservice teacher performance, disposition, and self-efficacy beliefs regarding systematic instructional planning. Educational Technology Research and Development, 49(4), 97. Retrieved from https://search.proquest.com/docview/218034286?accountid=31259

[27] Leithwood, K. (2006). Teacher working conditions that matter: Evidence for Change, 53-54. Elementary Teachers' Federation of Ontario. Retrieved from https://www.academia.edu/29343982/Teacher_Working_Conditio ns That Matter Evidence for Change

[28] Love, B., Hodge, A., Grandgenett, N., \& Swift, A. W. (2014). Student learning and perceptions in a flipped linear algebra course. International Journal of Mathematical Education in Science and Technology, 45(3), 317-324. https://www.tandfonline.com/doi/full/10.1080/0020739X.2013.82 2582

[29] Marks, H. M., \& Louis, K. S. (1997). Does teacher empowerment affect the classroom? The implications of teacher empowerment for Instructional Practice and student academic performance. JSTOR, 19(3), 245. doi:10.3102/01623737019003245 
[30] Monsen, J. J., Ewing, D. L., \& Kwoka, M. (2014). Teachers' attitudes towards inclusion, perceived adequacy of support and classroom learning environment. Learning Environments Research, 17(1),

113-126. https://link.springer.com/article/10.1007/s10984-013-9144-8

[31] Narciso, R. C. (2017). Work stress and performance of UM Tagum college (Master's thesiss). Retrieved from http://www.ijoart.org/docs/WORK-STRESS-ANDPERFORMANCE-OF-UM-TAGUM-COLEGE-FACULTY.pdf

[32] Okolo, R. (1993). A study of factors influencing job satisfaction among faculty members at selected historically black colleges and universities in Texas (Doctoral dissertation). Retrieved from https://digital.library.unt.edu/ark:/67531/metadc278297/m2/1/high res_d/1002720972-okolo.pdf

[33] Oswald, A. (2012). The effect of working environment on workers performance: The case of reproductive and child health care providers in Tarime Disctrict (Doctoral dissertation). Retrieved from

http://ihi.eprints.org/1658/1/Asigele_Oswald.pdf?bcsi_scan_3350 bd09186420d9=97Gsz

[34] Owoeye, J., \& Yara, P. (2011). School facilities and academic achievement of secondary school agricultural science in Ekiti State, Nigeria. Asian Social Science, 7(7), 64. doi:10.5539/ass.v7n7p64

[35] Reynolds, D. (2015). Effective school leadership: The contributions of school effectiveness research. Retrieved from https://www.researchgate.net/publication/252048271_Effective_sc hool_leadership_the_contributions_of_school_effectiveness_resea rch

[36] Safer, N., \& Fleischman, S. (2005). Research matters/how student progress monitoring improves instruction. Retrieved from http://www.ascd.org/publications/educationalleadership/feb05/vol62/num05/How-Student-ProgressMonitoring-Improves-Instruction.aspx

[37] Said, N. P., Zaidee, A., Zahari, A., Ali, S., \& Salleh, S. (2015). Relationship between employee motivation and job performance: A study at universiti Teknologi MARA. Mediterranean Journal of Social Sciences, 6(4), 2. doi:10.5901/mjss.2015.v6n4s2p632

[38] Skinner, N., Roche, A. M., O’Connor, J., Pollard, Y., \& Todd, C. (2005). Theory into practice strategies (TIPS): A resource kit for the alcohol and other drugs field, 2. National Centre for Education and Training on Addiction. Retrieved from http://nceta.flinders.edu.au/files/9312/4710/5740/Prof_Dev.pdf
[39] Stronge, J.H. (2012). Teacher effectiveness performance evaluation handbook. Retrieved from http://mnprek3.wdfiles.com/local--files/teacher-effectiveness/TEPES\%20$\% 20$ Stronge.pdf

[40] Stronge, J. H., \& Xu, X. (2012). CESA 6 Teacher performance evaluation system Retrieved from http://scholar.googleusercontent.com/scholar?q=cache:MtDjXMM zKfMJ:scholar.google.com/\&hl=en\&as_sdt $=0$

[41] Sultana, A., Irum, S., Ahmed, K., \& Mehmood, N. (2012). Impact of training on employee performance: A study of telecommunication sector in Pakistan. Interdisciplinary Journal of Contemporary Research in Business, 4(6), 647. Retrieved from https://www.researchgate.net/publication/274194048_Impact_of_t raining_on_employee_performance_A_study_of_telecommunicati on_sector_in_Pakistan

[42] Torbert, G. J. (2014). Exploring the perceptions of teachers and principals regarding the teacher keys effectiveness system in Georgia. Retrieved from https://search.proquest.com/docview/1642406799?accountid=3125 9

[43] Wittink, D.R., \& Bayer, L.R. (1994).The measurement imperative. Marketing Research, 6 (64), 14.

[44] Wittenberg, L. (2016). Become the leader you are self-leadership through executive coaching ( 2 nd ed.). Retrieved from https://irpcdn.multiscreensite.com/1c74f035/files/uploaded/become-theleader-you-are.pdf

[45] Wright, S., Horn, S., \& Sanders, W. (1997). Teacher and classroom context effects on student achievement: implications for teacher evaluation. Journal of Personnel Evaluation in Education, 11, 57-67. Retrieved from https://pdfs.semanticscholar.org/1677/01cd3fba9fdf5ef850eaca75b 1b101334ed2.pdf

[46] Yoon, K. H., Duncan, T., Lee, S., Scarloss, B., \& Shapley, K. (2007). Reviewing the evidence on how teacher professional development affects student achievement. Washington, DC: US. Department of Education, Institute of Education Sciences, National Center for Education Evaluation and Regional Assistance. Retrieved from https://ies.ed.gov/ncee/edlabs

[47] Zaldivar, V., Pardo, A., Burgos, D., \& Kloos, C. (2012). Monitoring student progress using virtual appliances: A case study. Science Direct. doi.org/10.1016/j.compedu.2011.12.003

[48] Zepeda, S. J. (2012). Professional development what w0orks, 3. 